\title{
Multi-modeling and multi-scale modeling as tools for solving complex real- world problems
}

\author{
B. Stojanovic ${ }^{*}$, M. Ivanovic ${ }^{1}$, A. Kaplarević-Malisic ${ }^{1}$, V. Simic ${ }^{1}$, M. Milivojevic ${ }^{2}$, Dj. \\ Nedic $^{1}$, M. Svicevic ${ }^{1}$, N. Milivojevic ${ }^{3}$, S. Mijailovich ${ }^{4}$ \\ ${ }^{1}$ University of Kragujevac, Faculty of Science, Kragujevac, Serbia \\ e-mail: bobi@kg.ac.rs \\ ${ }^{2}$ Technical and Business College, Uzice, Serbia \\ 3 "Jaroslav Cerni" Institute for the Development of Water Resources, Belgrade, Serbia \\ ${ }^{4}$ Department of Chemistry and Chemical Biology, Northeastern University, Boston, USA \\ *corresponding author
}

\begin{abstract}
In previous decades a number of computational methods for calculation of very complex physical phenomena with a satisfactory accuracy have been developed. Most of these methods usually model only a single physical phenomenon, while their performance regarding accuracy and efficiency are limited within narrow spatial and temporal domains. However, solving realworld problems often requires simultaneous analysis of several coupled physical phenomena that extend over few spatial and temporal scales. Thus, in the last decade, simultaneous modeling of a number of physical phenomena (multi-modeling) and modeling across few scales (multi-scale modeling) have gained huge importance. In this paper, we give an overview of multi-modeling and multi-scale methods developed during the last decade within the Group for Scientific Computing at the Faculty of Science, University of Kragujevac. In addition, we give a short review of accompanying problems that we had to be solved in order to make the methods applicable in practice, such as parallelization of computations, parameters calibration, etc.
\end{abstract}

In the first part of the paper we present methods for modeling various aspects of muscle behavior and their coupling into complex multi-models. The mechanical behavior of muscles is derived from the behavior of many individual components working together across spatial and temporal scales. Capturing the interplay between these components resulted in efficient multiscale model.

The rest of the paper is reserved for the presentation of multi-models for solving real-world problems in the field of water resources management, as well as methods for calibration of complex models' parameters. As the most illustrative example, we present methodology for solving the problem of water leakage under Visegrad dam at Drina River in Republic of Srpska. With the aim to support decision-making process during dam remediation, we have developed specialized multi-model that continuously uses the acquired observations to estimate spatial distribution of the main karst conductors, their characteristics, as well as hydraulic variables of the system. 
Keywords: modeling, simulation, optimization, finite elements, finite differences, Monte Carlo, linear regression, artificial neural networks, evolutionary algorithms

\section{Introduction}

Quantitative research challenges in almost every field of science require simultaneous analysis of several coupled physical phenomena. Capturing distinct aspects of a single problem in order to represent complex dynamic processes demands implementation and usage of multi-models (Johansen 1997). When a system in concern is the one which properties and behavior result from processes laid out over few spatial and temporal scales, a multi-scale modeling has to be employed. Multi-modeling and multi-scale modeling are ubiquitous, thus a progress in solving most of real-world problems is determined by our ability to design and solve such models of the particular systems under study. In the last decade, significant part of activities within the Group for Scientific Computing at the Faculty of Science University of Kragujevac was dedicated to design and usage of complex systems models in two major fields; the field of biomedicine, precisely muscle modeling, and the field of water resources management. While studying models and methodology for their development, we were considering and developing a strategy for efficient execution of such inherently computational demanding systems. These efforts resulted in usable models in terms of accuracy and feasibility.

In this paper we present a short review of the recent research results of the Group concerning multi-scale and multi-model systems. Section 2 considers results in a field of multiscale muscle modeling, while section 3 presents multi-models for solving real-world problems in the field of water resources management.

\section{Multi-scale model of muscle behavior}

Existing computational muscle models typically fall into two classes: (1) biophysical, focused on sub-cellular processes, and (2) phenomenological, which evaluate the performance of the whole muscle. The first, biophysical, are focused on sub-cellular processes. Most of them are evolved from the hypothesized crossbridge kinetic concepts originally formulated in Huxley (1957). Simulations of these kinetic processes, in the context of whole muscle models are tremendously computationally demanding. Therefore, models of whole muscles generally employ the second type of models, models that employ phenomenological concepts. Among them, the most widely used are the Hill-type models (Hill 1938). These models only take into account the relationship between active stress and strain rate, and their use is, therefore, limited to isometric and steady state contractions. Thus, the Hill model is often inadequate for simulations of motor physiology. Deficiencies in phenomenological approaches invite the development of multi-scale models of muscle contraction that employ models of molecular interactions to calculate the instantaneous macroscopic constitutive material characteristics necessary for quantitative models of whole muscle functional behavior.

In Stojanovic (2015), we proposed a multi-scale muscle model based on the finite element method and Huxley crossbridge kinetics model. In order to determine the mechanical response of a muscle, we implemented basic mechanical principles of motion of deformable bodies using finite element method. To determine constitutive properties of muscle we used Huxley's micro model based on sliding filament theory to calculate muscle active forces and instantaneous stiffnesses in FE integration points. 


\subsection{Finite element formulation}

A muscle is a material body which moves and deforms under external and internal loads. Therefore, it is a subject to the basic mechanical principles of motion of deformable bodies. In order to determine the mechanical response of a muscle we implemented method of solid mechanics analysis, precisely the finite element method. Fig. 1a shows a schematic representation of a muscle discretized into 3D finite elements.

(a) 2D Muscle

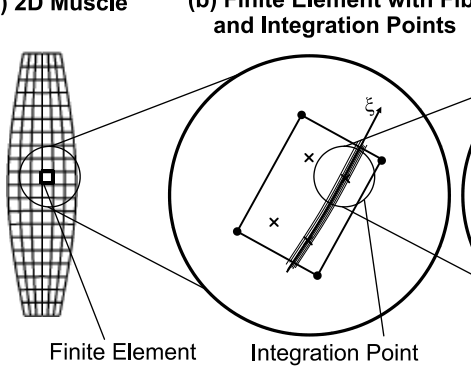

(c) Stretch

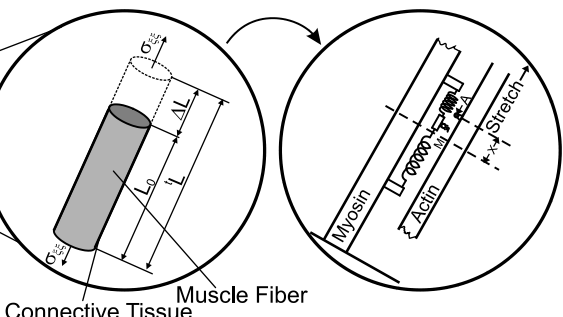

Fig. 1. Multi-scale model of muscle body contraction. a) Muscle body discretized into finite elements; b) diagram depicting the muscle fibers contained within a characteristic twodimensional (2D) FE, including denoted integration points and the principal direction muscle fibers, $\xi$; c) elongation of an individual muscle fiber, $\Delta L$, at the indicated spatial scale and under stress, $\sigma_{\xi \xi}$; d) Huxley crossbridge kinetics model

The constitutive properties of a muscle are defined by the number of molecular interconnections between the myosin and actin filaments. To account for these effects, the instantaneous material characteristics are prescribed on FE integration points, so-called Gaussian points Fig. 1.b.

The governing equilibrium equation of a FE structure in deformed configuration at time and iteration is formulated as:

$$
\left({ }^{t+\Delta t} \mathbf{K}_{e l}+{ }^{t+\Delta t} \mathbf{K}_{\text {mol }}\right){ }^{(i-1)} \delta \mathbf{U}^{(i)}={ }^{t+\Delta t} \mathbf{F}_{\text {ext }}^{(i-1)}+{ }^{t+\Delta t} \mathbf{F}_{\text {int }}^{(i-1)}+{ }^{t+\Delta t} \mathbf{F}_{\text {active }}^{(i-1)}
$$

where ${ }^{t+\Delta t} \mathbf{F}_{\text {ext }}^{(i-1)},{ }^{t+\Delta t} \mathbf{F}_{\text {int }}^{(i-1)}$, and ${ }^{t+\Delta t} \mathbf{F}_{\text {active }}^{(i-1)}$ are vectors of external physiological loads, internal (structural) nodal forces, and integrated active molecular forces lumped into FE nodal forces, respectively; ${ }^{t+\Delta t} \mathbf{K}_{e l}^{(i-1)}$ and ${ }^{t+\Delta t} \mathbf{K}_{m o l}^{(i-1)}$ are stiffness matrices of the passive components of constitutive FE and of cumulative stiffness of actomyosin bonds, respectively; $\delta \mathbf{U}^{(i)}$ are the increments of nodal displacements at iteration $(i)$; and the left-upper index $t+\Delta t$ indicates that the equilibrium equations correspond to the end of the time step. The continuum representation of muscle active stress in the $\mathrm{FE}$ formulation is denoted as nodal $\mathrm{FE}$ forces ${ }^{t+\Delta t} \mathbf{F}_{\text {active }}^{(i-1)}$ and of muscle stiffness as nodal FE stiffness, ${ }^{t+\Delta t} \mathbf{K}_{m o l}^{(i-1)}$.

The key step in a standard FE formulation is the evaluation of the element nodal internal and active forces:

$$
{ }^{t+\Delta t} \mathbf{F}_{\text {int }}^{(i-1)}+{ }^{t+\Delta t} \mathbf{F}_{\text {activ }}^{(i-1)}=\int_{{ }^{t+\Delta t} V^{(i-1)}}{ }^{t+\Delta t} \mathbf{B}_{L}^{T(i-1)}{ }^{t+\Delta t} \boldsymbol{\sigma}^{(i-1)} d V
$$


where ${ }^{t+\Delta t} \mathbf{B}_{L}^{T(i-1)}$ is the geometric linear strain-displacement matrix (superscript $\mathrm{T}$ means transpose), ${ }^{t+\Delta t} \boldsymbol{\sigma}^{(i-1)} d V$ is the stress tensor within the muscle, and ${ }^{t+\Delta t} \mathbf{V}^{(i-1)}$ is the volume of a FE. The index $(i-1)$ indicates the last known muscle configuration during the equilibrium iterations within the time step.

The material resistance to deformation across spatial scales can be calculated as:

$$
{ }^{t+\Delta t} \mathbf{K}_{\text {int }}^{(i-1)}+{ }^{t+\Delta t} \mathbf{K}_{\text {activ }}^{(i-1)}=\int_{t+\Delta t} V^{(i-1)}{ }\left({ }^{t+\Delta t} \mathbf{B}^{T}{ }^{t+\Delta t} \mathbf{C}^{t+\Delta t} \mathbf{B}\right)^{(i-1)} d V
$$

where $\mathbf{C}$ is the constitutive matrix representing the stress-strain relationship, ${ }^{t+\Delta t} \mathbf{K}_{m o l}^{(i-1)}$ and ${ }^{t+\Delta t} \mathbf{K}_{e l}^{(i-1)}$ define the contribution of variable stiffness of actomyosin bonds and the contribution of the passive component representing connective tissue, respectively.

This dynamic equilibrium of forces in (1), together with other boundary conditions and constraints, uniquely predicts the mechanical response of muscle tissues (Kojic M 2008). After assembling the element balance equations, the FE equilibrium equations for the entire muscle (1) are solved, securing the equilibrium of $\mathbf{F}_{\text {ext }}, \mathbf{F}_{\text {int }}$, and $\mathbf{F}_{\text {active }}$ within the prescribed tolerance at the end of each time step, $t+\Delta t$ (Bathe K J 2005; Kojic M 2005). The displacement vector $\mathbf{U}^{(i)}$ is updated during iterations by the current increment $\delta \mathbf{U}^{(i)}$, until $\delta \mathbf{U}^{(i)} \approx 0$ at the convergence. Active force generation, ${ }^{t+\Delta t} \mathbf{F}_{\text {active }}^{(i-1)}$, and stiffness, ${ }^{t+\Delta t} \mathbf{K}_{\text {mol }}^{(i-1)}$, are directly dependent on the rate of muscle deformation in the principal direction of muscle fibers (Mijailovich 2010, Kojic 2008). Therefore, the solution of the above equation includes the effects of straindependent modulation at various different length scales (McMahon 1984; Smith 2008).

\subsection{Huxley muscle model}

In 1957, Huxley proposed the model for isotonic contraction of striated muscle. One key component of this model is the definition of the rate functions that describe the biochemical reactions of the actomyosin cycle. Following Huxley, a muscle fiber constitutive unit is represented by interacting actin and myosin filaments (Razumova 1999). The spring-like connections between filaments generate in aggregate the active muscle force and stiffness (Kojic 2005).

The myosin heads act as thermal ratchet during binding process, where thermal fluctuations provide the energy to extend crossbridge element in order to reach the closest actin site. Because the binding is allowed only when the crossbridge spring is stretched, each freshly attached crossbridge contributes to active contractile force. The muscle active force and stiffness are calculated from fraction of attached crossbridges, $n(x, t)$ as a function of the crossbridge stretch, $x$, from its strain free position at time $t$. The process of continually attaching and detaching crossbridges is defined by attachment and detachment rates, $f(x)$ and $g(x)$. Huxley's sliding filament theory (McMahon 1984) is defined by the first order partial differential equation over the domain $\Omega$ :

$$
\frac{\partial n}{\partial t}(x, t)-v \frac{\partial n}{\partial x}(x, t)=\mathrm{N}(n(x, t), x), \quad \forall x \in \Omega
$$


where $v=-d x / d t$ is the shortening velocity of the thin filament with respect to the thick filament; $\mathrm{N}(n(x, t), x)=[1-n(x, t)] f(x)-n(x, t) g(x)$ is compounded transition flux between attached and detached states.

To simulate muscle mechanical function, we applied activation function. The attachment rate constant $f_{1}$ becomes the time-dependent function. Also, $f_{1}$ is a function of the muscle length and is structurally described by Gordon's tension-length relationship (Gordon 1966), where $f_{1}$ is modulated by the overlap of actin and myosin filaments between which the cycling cross bridges generate active force. The attachment rate is then defined as:

$$
f_{1}(t)=f_{0} \cdot \gamma_{k} \cdot \alpha(t)
$$

where $\alpha(t)$ is activation function of the muscle and $f_{0}$ is attachment rate under full activation, $\gamma_{k}$ is stretch dependent modulation factor.

The specific muscle tension arises from the distortion of the crossbridge represented as a linear spring and can be calculated from:

$$
\mathrm{F}(t)=\kappa \cdot \int_{-\infty}^{+\infty} x \cdot n(x, t) d x
$$

where $\kappa$ is the crossbridge stiffness. Specific instantaneous muscle stiffness is then defined by integral $\mathrm{K}(t)=\kappa \cdot \int_{-\infty}^{+\infty} n(x, t) d x$.

\subsection{Coupling FE and Huxley}

The active stress generated in muscle is calculated as

$$
\sigma_{m}=\mathrm{F} \frac{\sigma_{i s o}}{\mathrm{~F}_{\text {iso }}}
$$

where $\sigma_{i s o}$ is a maximal isometric stress, $F_{\text {iso }}$ is a maximal force calculated by Huxley's model for isometric contraction ( $v=0)$. The total stress $\overline{\boldsymbol{\sigma}}$ is expressed as the contribution of active muscle forces and the contribution of (passive) elasticity of collagenous connective tissue, cell membrane, and muscle noncontractile cytoskeleton in parallel to muscle cells:

$$
\overline{\boldsymbol{\sigma}}=\phi \overline{\boldsymbol{\sigma}}_{m}+(1-\phi) \overline{\boldsymbol{\sigma}}^{E}
$$

where $\phi$ is the fraction of muscle fibers in the total muscle volume and $\overline{\boldsymbol{\sigma}}^{E}$ is the stress in passive part of the muscle. Overscore denotes tensors that refer to the "local” coordinate system with the first axis in the fiber direction. The stress $\overline{\boldsymbol{\sigma}}_{m}$ has one nonzero component $\sigma_{m}$ in the direction of the fiber. Therefore, the total stress $\overline{\boldsymbol{\sigma}}$ is calculated as follows:

$$
\bar{\sigma}_{11}=\phi \sigma_{m}+(1-\phi) \bar{\sigma}_{11}{ }^{E} \quad \text { and } \quad \bar{\sigma}_{i j}=(1-\phi) \bar{\sigma}_{i j}{ }^{E} \quad \text { for other } i, j
$$

where $\overline{\boldsymbol{\sigma}}^{E}=\overline{\mathbf{C}}^{E} \overline{\mathbf{e}}$ is the passive stress, $\overline{\mathbf{C}}^{E}$ is the elastic constitutive matrix, and $\overline{\mathbf{e}}$ is the strain at material point of muscle. 
The tangent constitutive matrix $\overline{\mathbf{C}}$ of the muscle and connective tissue considered as a continuum is calculated as follows:

$$
\overline{\mathbf{C}}=\frac{\partial \overline{\boldsymbol{\sigma}}}{\partial \overline{\mathbf{e}}}=\phi \frac{\partial \overline{\boldsymbol{\sigma}}_{m}}{\partial \overline{\mathbf{e}}}+(1-\phi) \overline{\mathbf{C}}^{E}
$$

in which the terms are:

$$
\bar{C}_{11}=\phi \frac{\partial \sigma_{m}}{\partial \bar{e}_{11}}+(1-\phi) \bar{C}_{11}^{E} \quad \text { and } \quad \bar{C}_{i j}=(1-\phi) \bar{C}_{i j}^{E} \quad \text { for other } i, j
$$

where $\bar{C}_{i j}^{E}$ are elastic constitutive matrix terms of the surrounding connective tissue.

\subsection{Results}

The model features are tested on a simplified 2D geometry of a muscle body (Fig. 1a). The muscle body is modelled using two-dimensional 4-nodes finite elements where the fiber direction in each Gaussian point is assumed to follow the shape of the muscle. Huxley's micro model was defined with the following parameters: $\mathrm{f}_{1}=43.3, \mathrm{~g}_{1}=10.0, g_{2}=209.0, h=15.6$. The results calculated using FE-Huxley multi-scale model were compared to those obtained by an equivalent Hill's phenomenological model (Kojic 1998).

The main difference between Huxley's and Hill's material model is in simulations of transients and under variable external loads. To test these differences, we conducted two types of experiments. The first refered to isometric exercise in which muscle length did not change during contraction. In the second, we investigated muscle contraction under isotonic conditions. In all experiments stress and deformation fields under full activation of the muscle were calculated, while time step $\Delta t$ of performed simulations was set to $0.01 \mathrm{~s}$.

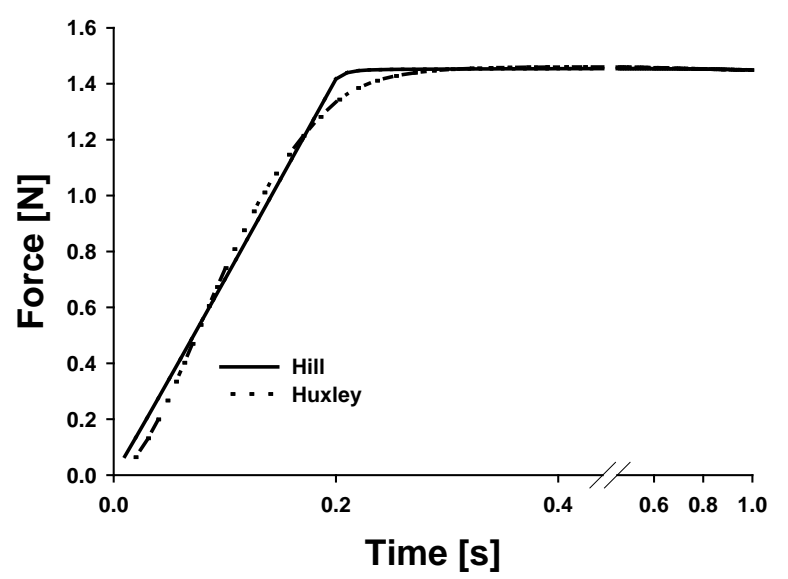

Fig. 2. Comparison between Hill’s model and Huxley’s model: force development

In the first experiment, evolution of force during force development is predicted. For both models the activation is gradually increased over the first 0.2 seconds. The predicted force by Hill's model is proportional to the activation (Fig. 2). In Huxley's model the activation is 
prescribed by linear increase in maximal binding rate, $f_{1}$. Because the isometric active force is calculated from crossbridge kinetics, it is not proportional to the level of activation, i.e., $f_{1}$.

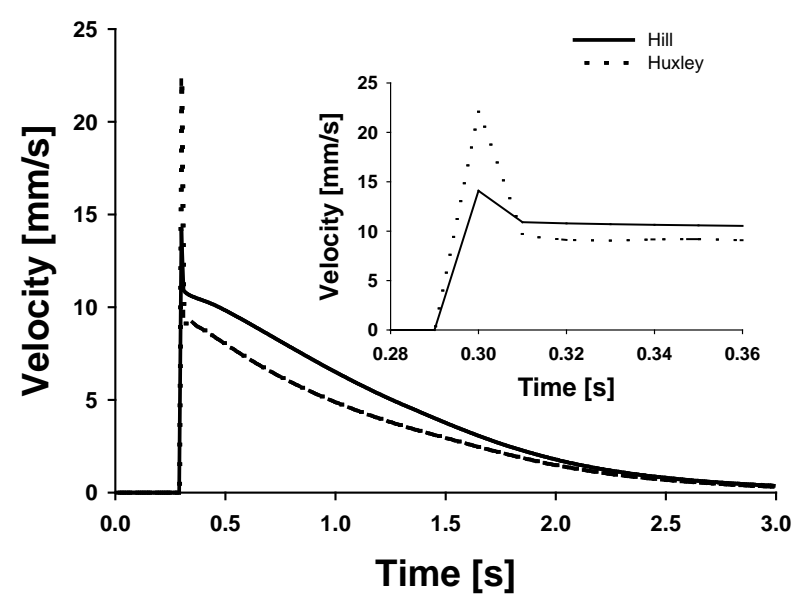

Fig. 3. Comparison between Hill's model and Huxley’s model: isotonic shortening velocities. Insert: large difference in transient velocities shortly after quick release

The second experiment is set to investigate how the difference in stiffnesses between the Huxley and Hill's material model affect the model dynamic behavior. The Huxley's model includes increase in muscle stiffness by attached crossbridges while Hill's model does not. For example, the large difference is shown in transients of velocities after isotonic quick release to $50 \%$ of $F_{\max }$ (Fig. 3). During force development the number of crossbridges increases and reaches maximum at maximum isometric force. After sudden decrease in force, the number of attached crossbridges is the same, but large number of them is exposed to high detachment rate causing large shortening velocities. As the number of attached crossbridges decreases, the velocity also decreases even below predicted with the Hill's model. At steady state, both velocities become the same. This example confirms that Hill's model is only valid in steady state situation. Also, applications of the Hill's model in physiology and medicine is significantly limited by lack of correlation between number of attached crossbridges and muscle stiffness.

Prior muscle models have been largely based on curve fitting from macroscopic experimental data, or used phenomenological Hill's three element model. Hill's model is strictly valid for steady state conditions only, e.g. isotonic steady state shortening, and does not include increase of muscle stiffness by attached cross bridges in the activated muscle. The twoscale FE/Huxley muscle model embodies concepts of multi-scale mechanics. Huxley's model includes increase in stiffness of attached cross-bridges at any instant and predicts much better transients after fast change in loading conditions, except the fast transients that require power stroke state transition. Inclusion of cross-bridge stiffness in instantaneous properties of a muscle provides opportunity to use developed multi-scale model in simulations of muscular organ function under relevant physiological loads. 


\subsection{Efficiency of the model}

Regarding the fact that multi-scale models are more informative and realistic, their practical implementation and usage in real-world applications is limited by their requirements for computational power. Due to the complexity of micro-model calculations, our multi-scale model is applicable only if we use some form of parallelization Thus, in order to run our multiscale model we have also developed a special parallelization strategy (Ivanovic M 2016). For our analyses we have developed the concept of distributed calculations in a mixed CPU-GPU environment. Finite element calculations of a macroscopic model take place strictly on the $\mathrm{CPU}$, while numerical solutions of the partial differential equations of micro model are calculated on both CPUs and GPUs.

We tested the feasibility of the proposed methodology on the real-world model of the complex muscle structure of the tongue. The multi-scale tongue model setup is identical to that described by Mijailovich S (2010). The model consists of 873 finite elements, with 3492 integration points. We simulated the lingual shape changes occurring following lingual tip contact with the hard palate during human swallowing, with a total duration of 0.5 seconds divided into 50 time steps. As a hardware platform, we used university cluster consisted of 22 nodes, each of them with dual Intel Xeon E5-2670@2.6GHz 8-core CPU, and 48GB memory, while four nodes were also equipped with Tesla M2090 accelerators with 6 GB of GDDR5 memory. Sequential execution of the simulation took approximately $96.06 \mathrm{~h}$, while 124 processes, run on CPU cores, and 4 GPU accelerated processes have completed the same task in 28.18 minutes, which is 204.53 times faster.

The developed parallelization strategy made the presented approach applicable to complex muscle structures, with various muscle groups, arbitrarily oriented in space, subjected to external loading and internal activation.

\section{Multi-modeling methodology for water resources management}

Solving real-world problems in the field of water resources management often requires simultaneous analysis of several coupled physical phenomena and thus imposes the usage of multi-models. Here we present such problem - water leakage under Visegrad dam at Drina River (Republic of Srpska), and multi-modeling methodology for solving it.

Water leakage under Visegrad dam was already observed in the first year of its exploitation. Further intensification of this phenomenon could have caused a variety of adverse effects, so it was necessary to repair the leaking by incorporating granulated materials in underground cavities. However, the sealing of underground karst conduits is a very complex process, which requires continuous monitoring and control. In order to make the right decisions through the process of sealing, a decision support system was established. This system evaluates the effects of the realization of technological processes almost in real time and helps decision-makers in planning their future activities. In order to implement such a decision support system an appropriate mathematical model was needed. The main task of the research performed on the mathematical model of groundwater flow was to use observations obtained through the monitoring system to continuously estimate the spatial distribution of the main karstic conduits, their physical characteristics, as well as the system's hydraulic variables and thus obtain the necessary information for deciding on optimal parameters of the process of remediation. Also, after the completion of the remediation, a mathematical model was used for carrying out a comprehensive estimation of the effects of the installation of granulated materials. 


\subsection{Description of the multi-model}

The mathematical model was developed as a set of components that simulate certain observed phenomenon, whereby all simulations are coupled with each other. This complex multi-model consists of three models: (1) the hydraulic model of karst groundwater flow; (2) the model for transport of solutes and (3) the model for transport and sedimentation of granulates. An initial hydraulic model of karst groundwater flow was created based on the previous geological investigations. It consisted of a 1D network of conduits that represent the hydraulic equivalent of the karst under the Visegrad dam (Fig. 4).

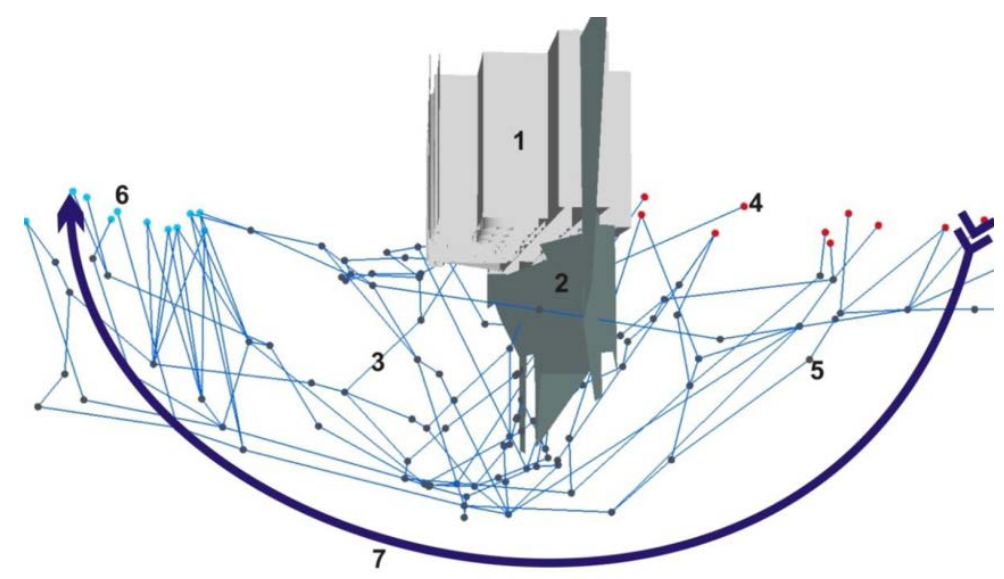

Fig. 4. 3D network of potential karst channels

The groundwater flow beneath the dam is the result of water flow under pressure through cracks in the soil, which is characterized by extremely high Reynolds numbers, due the dimensions of the cracks themselves, and the fact that the flows measured at some sinks reached values up to $10 \mathrm{~m}^{3} / \mathrm{s}$. Therefore, it was necessary to apply the following Darcy-Weisbach formula (Incopera et al. 2002) of turbulent flow in order to get relevant results of the hydraulic calculation:

$$
\Delta \varphi=\bar{\lambda} \frac{L}{D A^{2}} \frac{1}{2 g} Q^{2}
$$

where $\bar{\lambda}$ denotes Darcy-Weisbach's friction coefficient, $L, A$ and $D$ are length, cross-sectional area and the equivalent radii of conductivities.

Using a finite element solver for hydraulic calculations, simulation of the water flow through the model for the given boundary conditions (upstream and downstream elevation) was performed. In order to estimate the underground karst configuration and to calibrate the model, a number of measurements and experiments using various methods were carried out. A piezometric map was obtained using piezometers placed in the drill holes, while the flow velocities were measured at sinks and springs. In order to determine the main flow paths and dynamics, a number of experiments of salt and paint transport through the system were performed. The transport of solutes was modeled using the law of conservation of mass of dissolved matter which for the case of constant values of velocity $(V)$ and dispersion coefficient $\left(D_{L}\right)$ can be written as: 


$$
\frac{\partial C}{\partial t}=-V \frac{\partial C}{\partial x}+D_{L} \frac{\partial^{2} C}{\partial x^{2}}
$$

where $C$ denotes the concentration of solutes, $t$ is the time, $x$ is the axial coordinate of the conductor. Simulation of the salt and paint transport was executed using a finite difference solver for fluid mass transfer modelling.

The hydraulic model was further extended with the model for transportation of granulates which has been used to obtain parameters that were the main indicators for determining the optimal combination of different granulates, speed of their installation, etc. Input data for the calculation of granulates transportation were the adopted hydraulic model, the mass flow rate of installation material and characteristics of the grain (the diameter and density). As depicted in Fig. 5, the incremental procedure is performed alternately calculating the deposited material and hydraulic calculation model with altered characteristics of the pipe.

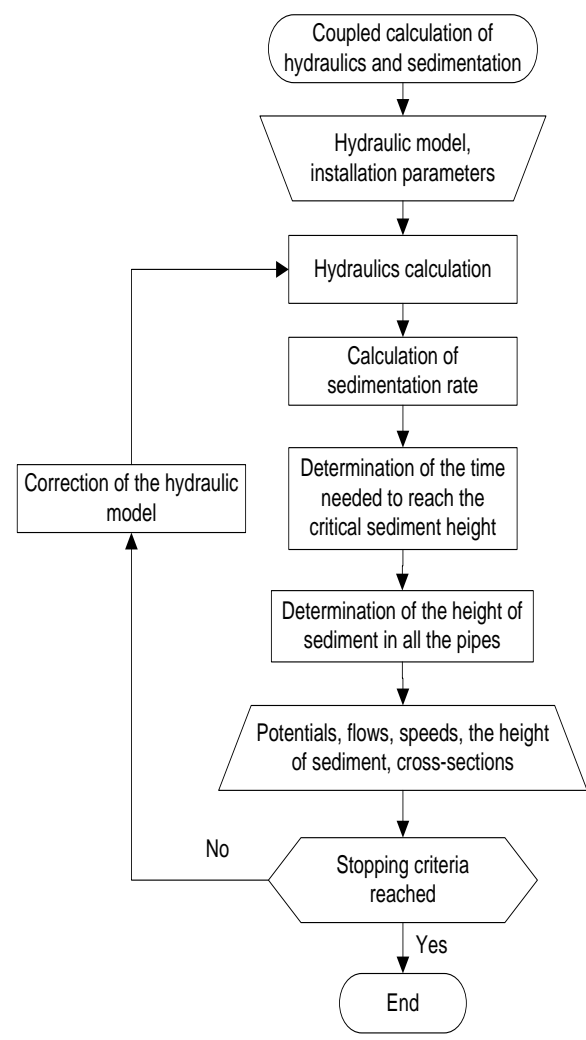

Fig. 5. The algorithm for calculation of transport and sedimentation of granulate

\subsection{Calibration of the multi-model}

The calibration of the described multi-model was preformed in several stages. At the first stage, before starting remediation, the multi-model was calibrated to estimate the current layout of the underground flows and the initial plan of remediation was made according to it. The result of this calibration was the determination of configuration zero, where configuration denotes current dimensions and resistance of conduits. This first calibration did not include the model for transport and sedimentation of granulates, which had a stake in the later calibrations in order 
to plan the installation of granulates. During the remediation process, the entire multi-model was repeatedly calibrated to reflect the state of the underground conduits at the selected key moments, since their dimensions and resistances changed over time due to the installation of inert material. Recalibration meant determining the values of certain parameters not only for the current configuration, but also for selected key configurations that have preceded it. Evaluation of compliance of each configuration with the real system status at a given point in time was determined on the basis of four indicators: (1) matching of the calculated and observed piezometric levels; (2) matching of the calculated and observed velocities at sinks and springs; (3) matching of the calculated dynamics of tracer transport with the dynamics measured on a real system; (4) matching of the calculated change in volume of channels in the underground network with the amount of installed granulate.

The model calibration was formulated as an optimization problem as follows: from the set of possible parameters of the model of groundwater flow determine those parameters that minimize the difference between the results obtained by the simulation models and values measured in the real system. Since four different criteria were used to assess the level of compliance of the model and the real physical system, the calibration came to multi-objective optimization. As such, the optimization problem was solved by NSGAII (Deb et al. 2002) multi-objective genetic algorithm (MOGA). Genetic algorithms (GA) approach for multiobjective optimization was chosen for GAs have proven themselves as a robust and powerful mechanism when it comes to solving challenging optimization problems (Coello Coello et al. 2007, Deb 2001).

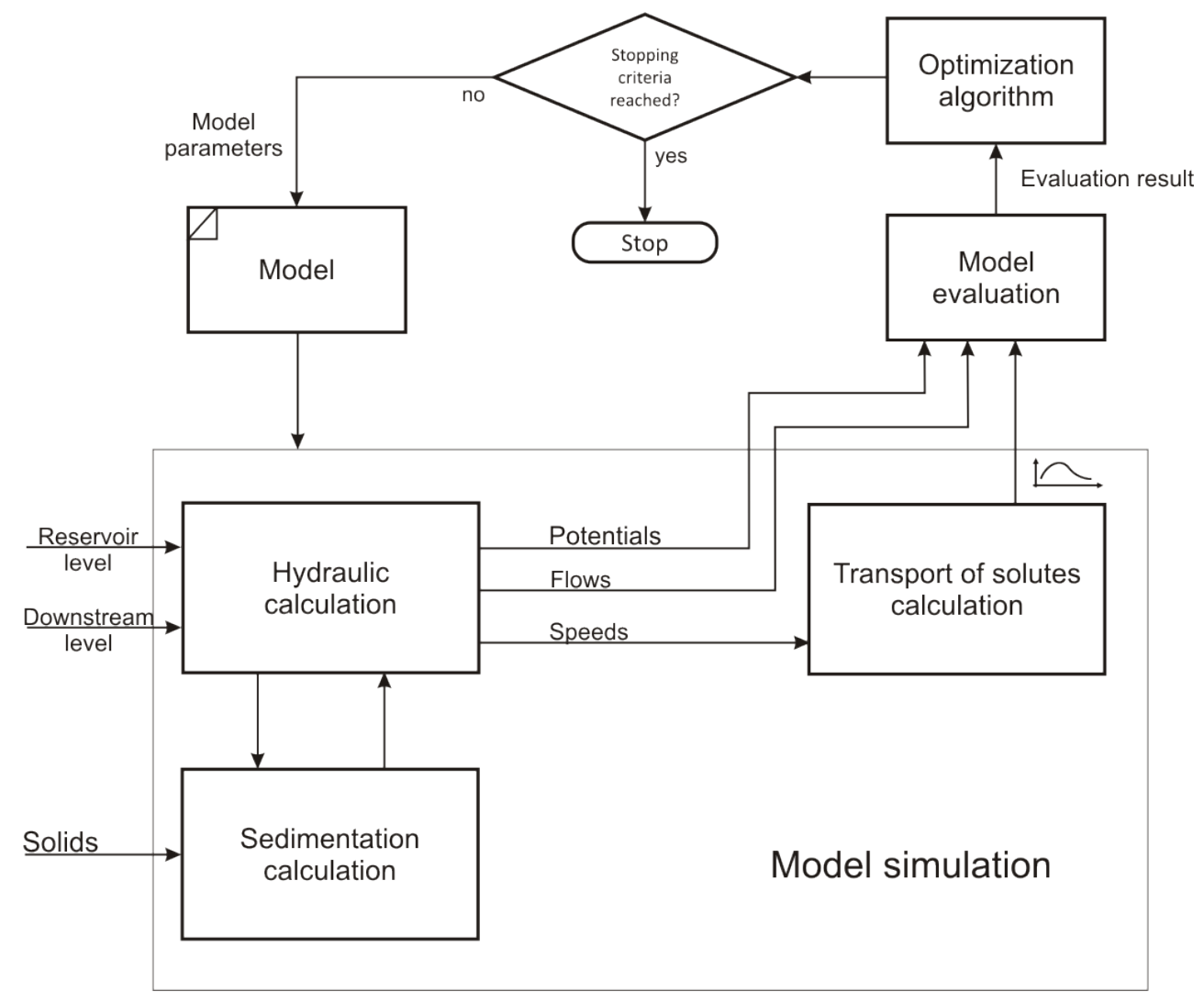

Fig. 6. The process of model's parameter estimation 
Fig. 6 shows the process of estimation of model parameters using GA. The process had begun with the creation of the initial population of model parameters, whereby the parameters for all elements of the configuration zero were assumed based on geological observations. Evaluation of each individual in a generation was done as follows:

1. Hydraulic calculations were carried out based on the assumed values of the parameters. The result of the calculations were the potentials, flows and speeds of the fluid in the model. Using the obtained flows, the tracer propagation was calculated. Then, the estimate of the validity of the the assumed set of parameters in configuration zero was gained by comparing the calculated and measured values of potentials, flows, speeds and time-series that represent tracer concentrations at certain locations of system.

2. Next, hydraulic calculations for other configurations of the model were performed. The parameters of these configurations, depended on the assumed parameters of the configuration zero as well as on the amount of installed granulate. The configurations were, independently from one another evaluated based on the first three criteria, after which the evaluation according to the fourth criteria was done. This evaluation took into account the fact that each configuration is a result of the effects of sedimentation on the previous configuration.

3. The assessment values of each configuration regarding one criterion were summed, thus forming the final assessment for the given criterion. This was done for each of the four criteria, and such determined four assessments were further used for ranking the individuals in population.

Algorithm then chose the best solutions based on their assessments. By crossing over those solutions a new generation is formed, and the process described in steps 1-3 starts all over again. After the satisfactory level of matching between measured and calculated values was gained, the algorithm was stopped, and the obtained results were declared as the most probable.

Previously described assessment of one individual lasts for an average of 66 seconds on one processor. The evaluation of generation of 500 individuals on a single processor would last almost 23 days. Thus, the duration of the entire calibration on a single processor would amount to more than 6 months, which is unacceptable for any practical usage. In order to speed up the calibration, the most time-consuming part of the algorithm - evaluation of individuals was distributed among as many processors as possible. This was accomplished by means of WoBinGO (Ivanovic et al. 2015) - A Parallel Framework for Genetic Algorithm Based Optimization. The framework is dedicated to parallel execution of single and multi-objective optimization using GA over heterogeneous resources, including HPC clusters and Globus-based Grids. It uses a master-slave parallelization model of GA where evaluation of individuals is separated from the rest of the algorithm and performed on distributed computing recourses working nodes. With WoBinGO framework, the duration of the entire calibration was significantly reduced to just over 10 hours when using an average of 484 processors for evaluating 500 individuals through 500 generations.

\subsection{Decision support system}

The extreme acceleration that was obtained through parallelization of calibration process enabled the use of a decision support system in almost real time and consequently ensured proper decision-making during the remediation process.

Besides the described calibration module contained on the simulation server, the decision support system contained user server, data base, acquisition server and measuring devices as pictured in Fig. 7. 


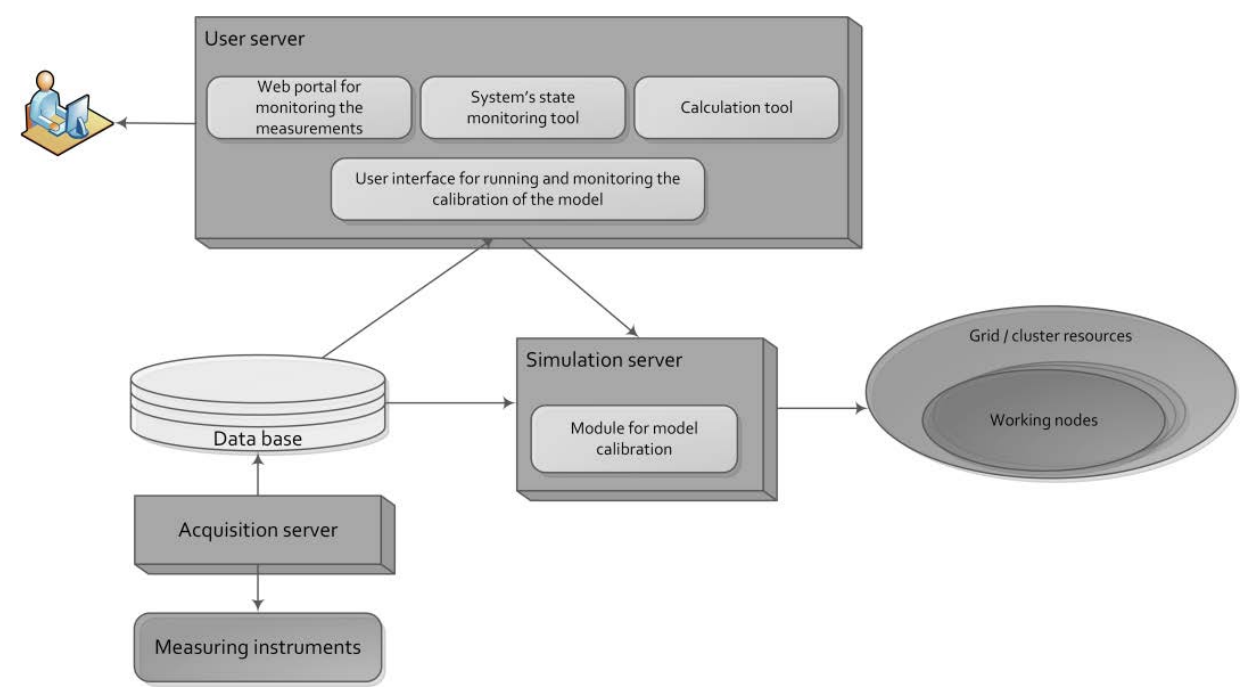

Fig. 7. Components of the decision support system

The software system was used in two modes: (i) in real time for a comparative overview and analysis of the calculated and the observed values of the selected parameters; (ii) occasionally to simulate the upcoming installation in order to select the optimal process parameters.

Near-realtime observation mode. When used in real time, system had provided user with visual information about the effects of solids installation on the changes of the values observed by monitoring system. Monitoring was carried out through the portal or through custom application for monitoring system's status.

Planning mode. Periodically, simulations of different scenarios of aggregate installation were executed using the calculation tool. The results were analyzed that pointed to a place and the amount of aggregate retention, changes in speed, flow and piezometer levels. The system's state could be analyzed in moments of occurrence of important events in the past period by moving along the time axis. Based on the analysis, optimal remediation process parameters were determined and periodical installation plans were defined.

\subsection{Results}

Using a calibrated mathematical model, satisfactory results were obtained as shown in the diagram (Fig. 8). The estimation of total leakage was regularly performed during the remediation (shown by the blue line in Fig. 8). The dynamics of installation of inert material was known, so it was possible to determine the quantities of materials that were retained in the system of karst channels. These quantities could be determined only in the moments that correspond to the defined configurations and are marked with red circles in Fig. 8. The initial estimated leakage was $14.03 \mathrm{~m}^{3} / \mathrm{s}$. After remediation, this value was reduced to $4.47 \mathrm{~m}^{3} / \mathrm{s}$, which indicates the importance of the performed works. The reduction of leakage was the consequence of the retention of the aggregate in the system of channels below the dam, and therefore Fig. 8 also shows the estimation of the retained aggregate. 


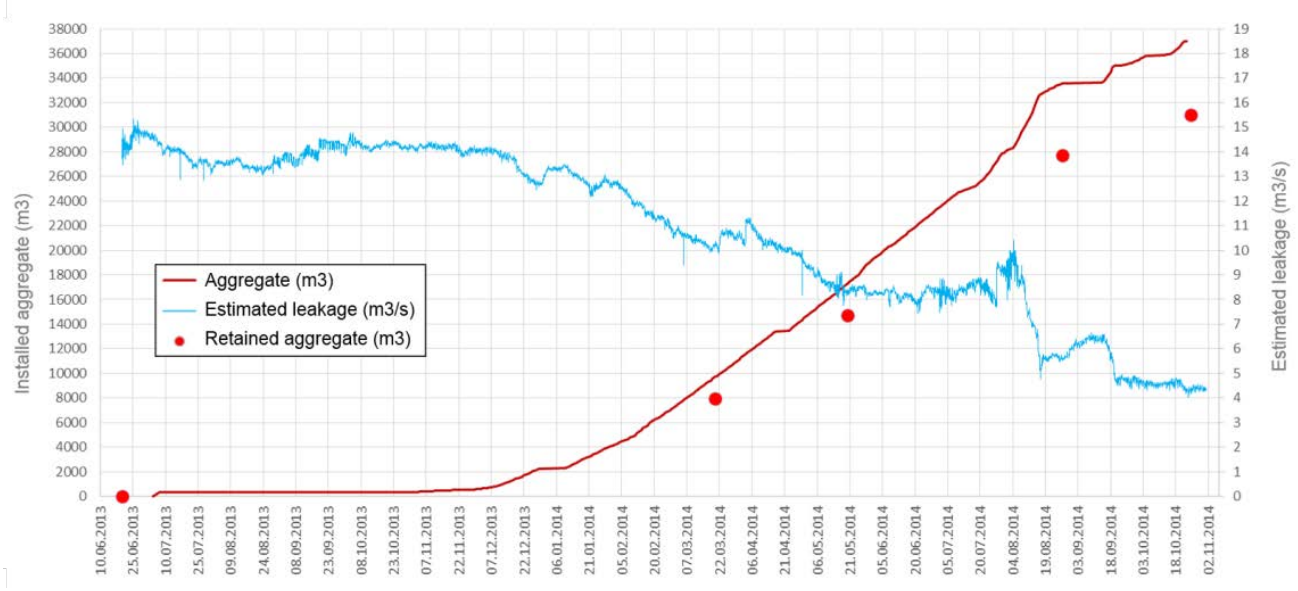

Fig. 8. Diagrams of installation of inert materials and the estimated leakage amounts of material retained in the individual configurations

\section{Conclusion}

In this paper a short review of the recent research results of the Group for Scientific Computing at Faculty of Science, University of Kragujevac, concerning multi-scale and multi-model systems is given.

We presented a novel methodology for multi-scale muscle modeling, where Huxley's micro model based on sliding filament theory is used to calculate muscle active forces and instantaneous stiffnesses in muscle material points, and used them to form continuummechanical constitutive laws at a macro level. Due to the developed parallelization strategy, application of the model to complex muscle structures, subjected to external loading and internal activation results is feasible, while quantitative results can be produced in reasonable time frame for real-world applications.

Within the field of water resource management, we presented the usage of multi-model for solving the real-world problem of water leakage under Visegrad dam. Additionally, we showed methods for calibration of complex models parameters which include parallel MOGA, and utilization of WobinGO framework, which ensured that unknown multi-model parameters were determined in reasonable time, thus enabling proper functioning of decision support system.

Acknowledgements. The authors acknowledge support of the Ministry of Education, Science and Technological Development of Serbia, grants OI174028, III41007, TR37013, and US National Institutes of Health AR048776 and DC011528. 
Извод

\title{
Мулти-моделовање и моделовање на више скала као алати за решавање сложених реалних проблема
}

\author{
Бобан Стојановић ${ }^{1 *}$, Милош Ивановић ${ }^{1}$, Ана Капларевић Малишић ${ }^{1}$, Вишња \\ Симић ${ }^{1}$, Милован Миливојевић ${ }^{2}$, Ђорђе Недић ${ }^{1}$, Марина Свичевић ${ }^{1}$, Никола \\ Миливојевић ${ }^{3}$, Србољуб Мијаиловић ${ }^{4}$ \\ ${ }^{1}$ Универзитет у Крагујевцу, Природно-математички факултет, Крагујевац, Србија \\ имејл: bobi@kg.ac.rs \\ ${ }^{2}$ Висока пословно-техничка школа, Ужице, Србија \\ ${ }^{3}$ Институт за водопривреду „Јарослав Черни“, Београд, Србија \\ ${ }^{4}$ Department of Chemistry and Chemical Biology, Northeastern University, Бостон, САД \\ * главни аутор
}

\section{Резиме}

У претходним деценијама развијен је велики број рачунарских метода за прорачун веома сложених физичких феномена са задовољавајућом прецизношћу. Већина ових метода најчешће моделује само један физички феномен, а њихове перформансе у погледу тачности и ефикасности су ограничене на уске просторне и временске домене. Међутим, решавање реалних проблема у највећем броју случајева захтева истовремено разматрање више спрегнутих физичких феномена, чија се област деловања простире на више просторних и временских скала. Из тог разлога су у претходној деценији симултано моделовање више различитих физичких феномена (multi-modeling) и моделовање на више скала (multi-scale modeling) добили огроман значај. У овом раду је дат преглед поменутих метода развијених током последње деценије у Групи за научно рачунарство Природно-математичког факултета Универзитета у Крагујевцу. Поред самих метода дат је и кратак осврт на пратеће проблеме које је било потребно решити како би ове методе биле примењиве у пракси, као што су паралелизација прорачуна, калибрација параметара и слично.

У првом делу рада је дат преглед метода за моделовање различитих аспеката понашања мишића и њихово повезивање у сложене мулти-моделе. Механичко понашање мишића је последица понашања великог броја појединачних компоненти, као што су електрична проводност ћелијске мембране и акциони потенцијал, динамика калцијума, кинетика хемијских реакција, и актомиозин циклус, који раде спрегнуто дуж више просторних и временских скала. Описивање узајамног дејства ових компоненти резултирало је ефикасним вишескалним моделом.

Други део рада је резервисан за приказ мулти-модела за решавање реалних проблема у управљању водним ресурсима, као и метода за калибрацију параметара тако сложених модела. Као један од најсликовитијих примера приказана је методологија решавања проблема санације процуривања на хидро-електрани Вишеград на реци Дрини у Републици Српској. У циљу подршке одлучивању приликом санације, развијен је одговарајући мулти-модел, чији је задатак био да, коришћењем добијених осматрања, у континуитету врши процену просторног распореда главних карстних проводника, њихових физичких карактеристика, као и хидрауличких величина у систему. 
Кључне речи: моделовање, симулација, оптимизација, коначни елементи, коначне разлике, Монте Карло, линеарне регресије, вештачке неуронске мреже, еволуциони алгоритми.

\section{References}

Coello Coello C A, Lamont G B, Van Veldhuizen D A (2007). Evolutionary Algorithms for Solving Multi-Objective Problems, 2nd ed, Springer, New York.

Deb K (2001). Multi-objective optimization using evolutionary algorithms, Wiley, UK.

Deb K, Pratap A, Agarwal S, Meyarivan T A M T (2002). A fast and elitist multiobjective genetic algorithm: NSGA-II, IEEE transactions on evolutionary computation, 6(2), 182197.

Gordon A M, Huxley A F, Julian F J (1966). The variation in isometric tension with sarcomere length in vertebrate muscle fibres, J. Physiol., 184, 170-192.

Huxley A F (1957). Muscle structure and theories of contraction, Prog. Biophys. Biophys. Chem, 7, 255-318.

Hill A V (1938). The heat of shortening and the dynamic constants of muscle, Proc. R. Soc. London B Biol. Sci, 126, 136-195.

Incopera F P, Dewitt D P, (2002). Fundamentals of Heat and Mass Transfer (5 ed.). John Wiley \& Sons, Inc. p. 470.

Ivanovic M, Simic V, Stojanovic B, Kaplarevic-Malisic A, Marovic B (2015). Elastic grid resource provisioning with WoBinGO: A parallel framework for genetic algorithm based optimization, Future Generation Computer Systems, 42, 44-54.

Ivanovic M, Stojanovic B, Kaplarevic-Malisic A, Gilbert R, Mijailovich S (2016). Distributed multi-scale muscle simulation in a hybrid MPI-CUDA computational environment. Simulation, 92, 19-31.

Kaplarević-Mališić A, Ivanović M, Stojanović B, Svičević M, Antonijević D (2015). Employing Phenomenological Model in Load-balancing Optimization of Parallel Multi-scale Muscle Simulations, $15^{\text {th }}$ International Conference on Bioinformatics and Bioengineering, Belgrade, Serbia

Kojic M, Bathe K J (2005). Inelastic analysis of solids and structures, Springer-Verlag Berlin Heidelberg

Kojic M, Filipovic N, Stojanovic B, Kojic N (2008). Computer modeling in Bioengineering, Theoretical Background, Examples Software, J Wiley Sons, Chichester

Kojic M, Mijailovic S, Zdravkovic N (1998). Modelling of muscle behaviour by the finite element method using Hill's three-element model, Int. J. Numer. Methods Eng., 43, 941953.

McMahon T A (1984). Muscles, reflexes and locomotion, Princeton University Press, New Jersey.

Mijailovich S, Stojanovic B, Kojic M, Liang A, Wedeen V J, Gilbert R J (2010). Derivation of a finite-element model of lingual deformation during swallowing from the mechanics of mesoscale myofiber tracts obtained by MRI, J. Appl. Physiol, 43, 941-953.

Razumova M V, Bukatina A E, Campbell K B (1999). Stiffness-distortion sarcomere model for muscle simulation, J. Appl. Physiol., 87, 1861-1876.

Smith D A, Mijailovich S M (2008). Toward a unified theory of muscle contraction. II: predictions with the mean-field approximation, Ann. Biomed. Eng., 36, 1353-1371.

Stojanović B, Svičević M, Kaplarević-Mališić A, Ivanović M, Nedić Đ, Filipovic N, Mijailovich S (2015). Coupling Finite Element and Huxley Models in Multiscale Muscle Modeling, $15^{\text {th }}$ International Conference on Bioinformatics and Bioengineering, Belgrade, Serbia 